4. Права потерпілих від насильницьких злочинів в Україні: міжнародні стандарти та національні практики / Орлеан А., Павлюковець Т., Крапивін Є., Лотюк Д., Човган В. Київ: «Видавничий дім «Артек», 2020. 206 c.

5. Directive 2012/29/eu of 25 October 2012 establishing minimum standards on the rights, support and protection of victims of crime. URL: https://eur-lex.europa.eu/legalcontent/EN/TXT/?qid=142192513161 4\&uri=CELEX:32012L0029 (last accessed: 30/03/2021).

DOI https://doi.org/10.30525/978-9934-26-074-2-66

\title{
ЗНАЧЕННЯ ЗАСАДИ ПРЕЗУМПЩІЇ НЕВИНУВАТОСТІ ТА ЗАБЕЗПЕЧЕННЯ ДОВЕДЕНОСТІ ВИНИ У КРИМІНАЛЬНОМУ ПРОВАДЖЕННІ
}

\author{
Парасюк М.В. \\ кандидат юридичних наук, дочент, \\ доцент кафедри иивільного права та процесу \\ Інституту права, психології та інноваційної освіти \\ Національного університету «Львівська політехніка» \\ м. Львів, Украӥна
}

Відповідно до п. 3 ч. 3 ст. 129 Конституції України, ст. 17 КПК України однією з засад кримінального судочинства презумпція невинуватості та забезпечення доведеності вини. У юридичній літературі відмічається, що реалізація конституційної вимоги щодо забезпечення вини можлива за умови дотримання таких вимог : 1) вимога імперативного характеру щодо «забезпечення», виявом якої в кримінальному процесі $є$ його публічність; 2) вимога щодо дотримання презумпції невинуватості як конституційної гарантії прав і свобод осіб, залучених до кримінального процесу; 3) доведеність вини як результат доказування, що врівноважує публічні та приватні інтереси суб'єктів кримінального процесу.

Саме унеможливлення притягнення до відповідальності невинних осіб являється основною метою принципу презумпції невинуватості, яка в свою чергу є однією із основних засад дотримання прав людини в демократичному суспільстві [1, С. 114].

Відповідно до п. 2 ч. 1 ст. 91, ч. 1 ст. 92 КПК України обов'язок доведення вини підозрюваного, обвинуваченого покладається на слідчого, прокурора. «Зміст цього обов’язку полягає, - як слушно зазначає Л. 
М. Лобойко, - у необхідності доводити вину, а не довести іi. Інакше на службових осіб державних органів довелося б покладати юридичну відповідальність за невиконання обов'язку. Відповідальність компетентних службових осіб встановлена лише за невжиття всіх заходів для встановлення вини особи. Тобто за неналежне здійснення процесу доказування, а не за отриманий в ході законного і об'єктивного доказування результат - не встановленням вини обвинуваченого» $[2$, с. 88].

Так, слідчий може вручити особі письмове повідомлення про підозру тільки за наявності доказів, достатніх для прийняття цього рішення (п. 3 ч. 1 ст. 276 КПК України). Це означає, що в розпорядженні слідчого має бути така сукупність належних, достовірних та допустимих доказів, які переконують його у тому, що : - розслідуване суспільне небезпечне діяння мало місце; - його вчинено умисно або необережно саме даною особою; - у цьому діянні $є$ всі передбачені кримінальним законом ознаки складу певного злочину.

Поки слідчий на підставі зібраних та перевірених доказів не дійде достовірного висновку про винуватість особи у вчиненні кримінального правопорушення та не сформулює його у обвинувальному акті, він зобов'язаний в силу вимог ч. 1 ст. 62 Конституції України, ч. 1 ст. 17 КПК України виходити з припущення про невинуватість підозрюваного.

3 такого припущення повинен виходити і прокурор, підтримуючи державне обвинувачення у суді, хоча він приходить до суду, щоб довести обгрунтування свого твердження про винуватість обвинуваченого у вчиненні кримінального правопорушення, довести істинність висновків обвинувального акту і достовірність фактів, що лежать в його основі.

Тягар доказування вини покладається на потерпілого й у випадку, передбаченому ст. 338 КПК України. Дійшовши до переконання, що обвинувачення потрібно змінити, прокурор складає обвинувальний акт та викладає обгрунтування прийнятого рішення. Якщо в обвинувальному акті зі зміненим обвинуваченням ставиться питання про застосування закону України про кримінальну відповідальність, який передбачає відповідальність за менш тяжке кримінальне правопорушення, чи про зменшення обсягу обвинувачення, головуючий зобов'язаний роз'яснити потерпілому його право підтримувати обвинувачення у раніше пред'явленому обсязі.

Нормативне положення про те, що особа, яка обвинувачується у вчиненні злочину, вважається невинуватою доки іії вину не буде встановлено у визначеному законом порядку, знайшло своє відображення у найважливіших міжнародно-правових актах, які закріпили універсальні стандарти основних прав і свобод людини, зокрема: Загальній декларації прав людини (п. 1 ст. 11); Міжнародному пакті про громадянські 
і політичні права (п. 2 ст. 14); Свропейській конвенції прав людини і основоположних свобод (п. 2 ст. 6). Власне, перелічені міжнародні нормативно-правові акти визначили той універсальний перелік прав $\mathrm{i}$ свобод, який у своїй єдності має забезпечити нормальну життєдіяльність людини в суспільстві і який знайшов своє закріплення переважно в основних законах держав, що визнали названі акти, в тому числі і в Конституції України. При цьому слід підкреслити, що право особи на презумпцію невинуватості у вітчизняній Конституції визначено більш повно і чіткіше, аніж у перелічених міжнародно-правових актах. [3, с. 7].

Презумпція невинуватості розглядається у вузькому та широкому значеннях, або іншими словами, на двох різних рівнях - при розгляді кримінальної справи в суді (англ. criminal trial) та в кримінальному процесі у більш загальному значенні3 . Вужча концепція охоплює відомий принцип, відповідно до якого при обвинуваченні особи у вчиненні злочину (чи кримінального проступку) тягар доведення вини несе сторона обвинувачення (прокурор), і доведення має бути поза розумним сумнівом (англ. beyond reasonable ground).

Нормативне закріплення презумпції невинуватості - необхідна, проте недостатня умова іiі дотримання. Практика свідчить, що заходи, які вживаються урядами навіть держав «старої демократії» при виконанні однієї з головних функцій сучасної держави - гарантуванні належного захисту громадян від злочинних посягань - демонструють намаганя обійти, знівелювати, применшити презумпцію невинуватості задля «громадської безпеки» (англ. public safety), перевага якій надається над правами людини.

В Україні презумпцію невинуватості найчастіше порушують у 3 випадках: при виголошенні публічних заяв політиками і прокурорами про чиюсь винуватість задовго до закінчення судового процесу, коли судове рішення, що не є обвинувальним вироком, відображає думку про винуватість особи, та під час затримання осіб, підозрюваних та/або обвинувачуваних у вчиненні злочину, і обранні щодо них запобіжного заходу [4, с. 47].

Таким чином, переконання названих осіб на суб'єктивному рівні (внутрішнє переконання) не спростовує презумпції невинуватості. Для іiі спростування необхідне зовнішне переконання у наявності вини обвинуваченої особи, переконання всіх, яке настане лише після встановлення вини особи судом в результаті розгляду та вирішення кримінального провадження (справи) і ухвалення ним обвинувального вироку. Визнати ж особу винною у вчиненні злочину, а також піддати іiі кримінальному покаранню інакше як за вироком суду в демократичній державі неможливо. 


\title{
Література:
}

1. Кошель В.В., Павлов Р.В. Сучасні аспекти презумпції невинуватості та забезпечення доведеності вини як засади кримінального провадження. Молодий вчений» - № 11 (63) - листопад, 2018 р. C. $114-117$.

2. Лобойко Л. М. Кримінальний процес / Л. М. Лобойко : підруч. К. : Істина, 2014. $432 \mathrm{c.}$

3. Нор В.Т. Презумпція невинуватості як конституційна засада кримінального судочинства та ії застосування в практиці Європейського суду 3 прав людини. Часопис Національного університету «Острозька академія». Серія «Право». 2011. № 1(3). С. 1-24

4. Фулей Т. Презумпція невинуватості: концептуальні підходи. Засади і принципи судочинства. Слово національної школи суддів України № 1(1). 2012 С. 39-53

DOI https://doi.org/10.30525/978-9934-26-074-2-67

\section{ПРОБЛЕМНІ ПИТАННЯ ПРАВОВОГО РЕГУЛЮВАННЯ ЗАБЕЗПЕЧЕННЯ УЧАСТІ ПОНЯТИХ У КРИМІНАЛЬНОМУ ПРОВАДЖЕННІ}

\author{
Піддубна А. В. \\ кандидат юридичних наук, \\ доцент кафедри кримінального проиесу \\ та організаиії досудового слідства \\ факультету № 1 \\ Харківського національного університету внутрішніх справ \\ м. Харків, Украӥна
}

Одним із проблемних питань кримінального процесу України $є$ теоретичне переосмислення та практичне застосування процесуального інституту понятих, який було поновлено у 2012 році при прийнятті чинного КПК України. Питання статусу та залучення понятих як учасників кримінального провадження до участі у проведенні слідчих (розшукових) дій досліджували у своїх працях такі відомі вчені правознавці, як: Ю. П. Аленін, Ю. І. Азаров, В. П. Бахін, І. М. Бацька, А. Р. Бєлкіна, Р. С. Бєлкін, О. Л. Булейко, А. Ф. Волобуєв, В. І. Галаган, Ю. М. Грошевий, В. О. Коновалова, А. А. Котова, С. Д. Лукянчиков, В. Т. Маляренко, О. Р. Михайленко, В. Т. Нор, М. А. Погорецький, 